\title{
Factors influencing bacterial attachment to the ruminal epithelium in vitro
}

\author{
Qingxiang Meng ${ }^{\dagger}$ and Rodney L. Preston* \\ Department of Animal Science, Texas Tech University, Lubbock, Texas 79409-2141, U.S.A.
}

(Received March 3, 1997; Accepted January 21, 1998)

\begin{abstract}
Some factors influencing bacterial attachment to the rumen epithelium were studied in vitro using mixed rumen bacteria (upper- or lower-layer bacteria formed at bacterial sediment by centrifugation), isolated from steers fed a roughage diet, and rumen epithelial cells collected from beef cattle given low-concentrate $(50 \%$; LC) and high-concentrate $(90 \% ; \mathrm{HC})$ diets. Optimal incubation conditions for bacterial attachment to rumen epithelial cells were $39^{\circ} \mathrm{C}$ for $30 \mathrm{~min}$. The bacteria isolated from the upper layer had a higher attaching activity to the LC epithelial cells than those of the lower layer. A higher degree of bacterial attachment was observed using the rumen epithelium from steers fed the LC diet rather than the HC diet $(p<0.01)$. Ethylenediamine dihydroiodide (EDDI) added at 10 through $40 \mu \mathrm{g} \mathrm{I} / \mathrm{ml}$ increased bacterial attachment to the $\mathrm{HC}$ epithelial cells. Ammonia at 50 through $100 \mu \mathrm{g} / \mathrm{ml}$ positively affected bacterial attachment to both LC and HC epithelial cells. Bacterial attachment to the $\mathrm{HC}$ epithelial cells was enhanced $(p<0.01)$ by the addition of a reducing agent (L-cysteine $\cdot \mathrm{HCl}$ ) but no increase was noted with LC cells. L- or D-lactate, volatile and unsaturated fatty acids markedly decreased bacterial attachment to rumen epithelial cells.
\end{abstract}

Key Words_— cattle; in vitro attachment; rumen epithelia; ruminal bacteria

The attachment of bacteria to rumen epithelia has been documented (Bauchop et al., 1975; Dinsdale et al., 1980; McCowan et al., 1978, 1980; Rieu et al., 1990; Wallace et al., 1979). Bacterial attachment may assist the digestion of dead epithelial tissues (Dinsdale et al., 1980), hydrolysis of endogenous urea (Cheng and Wallace, 1979) and the scavenging of oxygen by the rumen wall bacterial population in the rumen (Cheng and Costerton, 1980; Cheng and Wallace, 1979). There is little information regarding the factors affecting bacterial attachment to rumen epithelial cells. Electron microscopy studies revealed that polysaccharides or glycocalyx components on bacteria play a role in their attachment to rumen epithelial cells (Latham et al., 1978; McCowan et al., 1978). In another electron microscopy study, we observed that the rumen epithelial surface obtained from steers fed a low-concentrate diet was more densely populated by bacterial flora than that from animals fed a highconcentrate diet (Meng and Preston, 1994). This re-

\footnotetext{
* Address reprint requests to: Dr. R. L. Preston, Department of Animal Science, Box 42141, Texas Tech University, Lubbock, Tx 79409-2141, U.S.A.

†Visiting scientist from China Agric. Univ., Beijing 100094, The People's Republic of China.
}

sult suggested that the bacterial flora attaching to the reticulo-rumen epithelium is greatly affected by the diet. The purpose of this study was to investigate the effect of diet-related factors on bacterial attachment to ruminal epithelia. Because it is hard to control the attachment condition in vivo, an in vitro attachment model system was used in this study.

\section{Materials and Methods}

Isolation of ruminal bacteria. Ruminal contents were withdrawn from 3 ruminally fistulated crossbred steers fed a roughage diet consisting of medium quality alfalfa hay, and strained through 2 layers of cheesecloth anaerobically. The strained ruminal fluid was centrifuged at $1,000 \times g$ for $5 \mathrm{~min}$ at $4^{\circ} \mathrm{C}$ to remove protozoa and feed particles. The supernatant was then centrifuged at $20,000 \times g$ for 30 min to sediment bacteria. At this stage, sedimentary bacteria were fractionated into two layers, floating upper $(U)$ and pelleted lower $(L)$. Thus, the whole, $U$ and $L$ fractional bacteria were separately collected. The bacterial pellet was anaerobically suspended in Coleman's simplex-type solution (CSTS; Coleman, 1987), vortexed and centrifuged at $20,000 \times g$ for $30 \mathrm{~min}$. The washing procedure was repeated 3 times. The washed bacte- 
rial pellet was finally resuspended in CSTS and cell density adjusted to $2.5 \times 10^{8} \mathrm{cell} / \mathrm{s} / \mathrm{ml}$. After gassing with oxygen-free $\mathrm{CO}_{2}$, the suspension was sealed and stored at $4^{\circ} \mathrm{C}$ no longer than 3 days until use.

Preparation of ruminal epithelial cell suspension. Six crossbred beef cattle were divided into two groups; each group (three animals) was fed, for six months, a low-concentrate (LC; $50 \%$ concentrate) or high-concentrate (HC; 90\% concentrate) diet which consisted of steam-flaked milo, mineral-vitamin premix and cottonseed hulls. The animals were slaughtered in the Meat Laboratory, Texas Tech University. The rumen was rapidly exteriorized, and pieces of rumen wall about $6 \mathrm{~cm}$ square were removed from the dorsal and ventral sacs of each animal. The tissue pieces were placed on ice immediately after sacrifice and processed within $2 \mathrm{~h}$. After being roughly washed under cold $\left(4^{\circ} \mathrm{C}\right)$ tap water, the tissue pieces were washed several times with fresh cold phosphatebuffered saline (PBS, $4^{\circ} \mathrm{C}, \mathrm{pH} 7.2,0.01 \mathrm{~m}$ ) until the washing solution was free of debris. Epithelial cells were collected by scraping rumen papillae with the edge of a glass slide. Cells from all tissue samples of the animals fed the same diet were pooled and suspended in Eagle's minimal essential medium (MEM; Freshney, 1994) containing $100 \mathrm{U} / \mathrm{ml}$ of penicillin-G (potassium salt) and $50 \mu \mathrm{g} / \mathrm{ml}$ of streptomycin (Sigma Chemical Co., St. Louis, MO, U.S.A.), then magnetically stirred for $2 \mathrm{~h}$ at room temperature to remove most of the colonized bacteria (usually more than 20 bacteria per cell) from the epithelial cells. After 5 washings with MEM followed by centrifugation at $185 \times g$ for $5 \mathrm{~min}$, the cells were suspended in a solution containing $50 \%$ calf serum (freshly prepared in this laboratory), 30\% glycerol and 20\% MEM. The preparation was then stored at $-70^{\circ} \mathrm{C}$.

Attachment assay. The attachment of ruminal bacteria to rumen epithelial cells was measured using an in vitro assay based on a modification of the method described originally by Pal and Ghose (1990). Before the experiment, the frozen epithelial cell suspension was rapidly thawed at $37^{\circ} \mathrm{C}$, washed three times with MEM, and then suspended to a concentration of $5 \times 10^{6} \mathrm{cell} / \mathrm{s} / \mathrm{ml}$. The rumen bacterial suspension $(0.1 \mathrm{ml})$ was mixed with rumen epithelial cell suspension $(0.1 \mathrm{ml})$ and CSTS $(0.3 \mathrm{ml})$. The bacterium/ epithelial cell ratio of the mixture was ca. 50:1. After incubation, the cell suspension was washed two times with $15 \mathrm{ml}$ of cold PBS followed by centrifugation at $185 \times g$ for $5 \mathrm{~min}$. The supernatant containing unattached bacteria was discarded, and the epithelial cells with attached bacteria were fixed with $1.0 \mathrm{ml}$ of $2.5 \%$ glutaraldehyde (Sigma grade II, 25\% aqueous solution) in PBS for $2 \mathrm{~h}$ at $0-4^{\circ} \mathrm{C}$. When fixing was finished, cells were washed two times with cold PBS and centrifuged. The washed pellet was smeared on a glass slide with a minimal amount of PBS. Smears were allowed to air dry, stained with Weight-Giemsa (Sigma) and examined with a light microscope (Olympus, Model CHT, Tokyo, Japan) at 1,000× magnification. The number of attached bacteria per cell was counted in at least 20 cells for each smear. All assays were performed in triplicate; 60 cells were examined in each sample. A blank test was performed by counting bacteria colonized on epithelial cells without the addition of the bacterial suspension. Means ( \pm standard errors) of attached bacteria per cell were calculated.

The effects of different incubation temperatures (4, 25 and $39^{\circ} \mathrm{C}$ ) and times $(15,30,60$, and $120 \mathrm{~min})$ on the degree of attachment were tested.

Effect of diet-related factors on attachment. Ethylenediamine dihydroiodide (EDDI, containing 79.8\% iodine, Ajay Chemical Inc., Powder Springs, GA, U.S.A.), ammonium bicarbonate, L-cysteine $\cdot \mathrm{HCl}$, Land D-lactic acid, oleic acid, linoleic acid or arachidonic acid (Sigma), acetic acid, propionic acid or butyric acid (Fisher Scientific, Pittsburgh, PA, U.S.A.) were dissolved in or diluted with CSTS. Each solution $(0.3 \mathrm{ml})$ replacing an equal volume of CSTS in the attaching mixture, was mixed with ruminal bacterial suspension $(0.1 \mathrm{ml})$ and rumen epithelial cell suspension $(0.1 \mathrm{ml})$, and then incubated in a waterbath. Incubation temperature and time used would depend on the results of the experiment designed for the determination of effects of incubation temperature and time on attachment. Washing, smearing, staining and microscopic observation procedures were the same as described above. All experiments were run three times with three replications for each run. An attachment index was calculated as the number of bacteria attached per epithelial cell, expressed as a percentage of the number of bacteria attached in the control.

Statistical analysis. The means of attached bacteria in 20 epithelial cells for an individual test constituted a unit of observation. Means and standard errors were calculated from three separate experiments. Depending on the experimental objective, mono- or multiple factorial experimental designs were adopted. Statistical difference was assessed using the GLM procedure of SAS (SAS, 1989).

\section{Results}

\section{Effect of incubation temperature and time}

Both incubation temperature and time had a significant effect $(p<0.001)$ on bacterial attachment to the rumen epithelium. Maximum attachment occurred at $39^{\circ} \mathrm{C}$, although no difference $(p>0.30)$ was detected between 25 and $39^{\circ} \mathrm{C}$ with $\mathrm{HC}$ epithelial cells (Fig. 1). 
Attachment increased $(p<0.01)$ when incubation time was extended from 15 to $30 \mathrm{~min}$ (Fig. 2), but no further increase in attachment $(p>0.10)$ was observed beyond this time. Therefore, $39^{\circ} \mathrm{C}$ and $30 \mathrm{~min}$ were chosen for subsequent experiments.

\section{Effect of bacterial fractions and epithelial sources on attachment}

When rumen epithelial cells from steers fed the LC and $\mathrm{HC}$ diets were exposed to the $\mathrm{U}$ and $\mathrm{L}$ bacterial

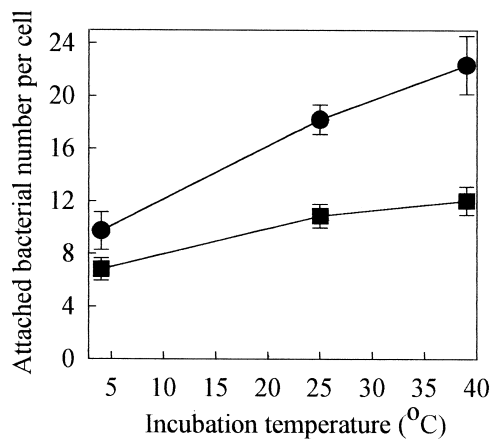

Fig. 1. Effect of incubation temperature on attachment of mixed bacteria on rumen epithelial cells.

Incubation time was $30 \mathrm{~min}$. Results are presented as means and standard errors (bars) of three experiments $(n=9)$. Rumen epithelial cells were from steers fed: $\bullet$, LC diet; $\mathbf{\square}$, HC diet.

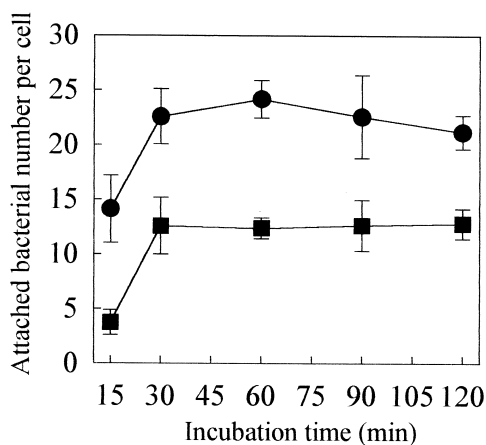

Fig. 2. Effect of incubation time on attachment of mixed ruminal bacteria to rumen epithelial cells.

Incubation temperature was $39^{\circ} \mathrm{C}$. Results are presented as means and standard errors (bars) of three experiments $(n=9)$. Rumen epithelial cells were from steers fed: $\bullet$, LC diet; $\mathbf{\square}, \mathrm{HC}$ diet. fractions, bacterial fractions, epithelial sources and their interaction significantly affected bacterial attachment to the rumen epithelial cells $(p<0.01)$. More bacteria from both $U$ and $L$ fractions attached to the $L C$ epithelial cells $(p<0.01)$ than to the HC cells (Table 1$)$. The $U$ fractional bacteria had a higher attaching activity $(p<0.01)$ to the $L C$ epithelial cells than the $L$ fractional bacteria, whereas, there was no significant difference $(p>0.05)$ between $U$ and $L$ fractions for the attachment to $\mathrm{HC}$ epithelial cells. These results suggest that the extent of bacterial attachment to the ruminal epithelium is dependent not only on the bacterial fraction but also on the source of the epithelial cells.

\section{Effect of diet-related factors on attachment}

Because of the higher attaching activity of the $U$ fractional bacteria to the LC epithelial cells (Table 1), this fraction was used to study the effect of diet-related factors on bacterial attachment to the rumen epithelium from steers fed the LC or HC diet. EDDI is commonly included in beef cattle rations to supply organic iodine. An oral dosage of $50 \mathrm{mg} \mathrm{I} \cdot$ day $^{-1} \cdot$ head $^{-1}$ for prophylaxis of iodine deficiency symptoms and a dosage of 400 to $500 \mathrm{mg} \mathrm{I} \cdot$ day $^{-1} \cdot$ head $^{-1}$ for treatment of footrot were used. When EDDI was added with $\mathrm{HC}$ epithelial cells at a concentration of 10 through $40 \mu \mathrm{g} \mathrm{I} / \mathrm{ml}$, bacterial attachment was enhanced $(p<0.05)$ as compared to the control. With EDDI concentration increased from 10 to $20 \mu \mathrm{g} \mathrm{l} / \mathrm{ml}$, a positive response was also noted on attachment with the LC epithelial cells ( $p=0.06$; Fig. 3 ). An inhibitory effect was observed when the EDDI concentration reached $40 \mu \mathrm{g} \mathrm{I} / \mathrm{ml}$ for the LC epithelial cells and $80 \mu \mathrm{g}$ $\mathrm{l} / \mathrm{ml}$ for the $\mathrm{HC}$ cells used.

Ammonia added at $50 \mu \mathrm{g} \mathrm{NH}-\mathrm{N} / \mathrm{ml}$ increased bacterial attachment to the LC epithelial cells $(p<0.05)$ and at 50 through $100 \mu \mathrm{g} \mathrm{NH}-\mathrm{N} / \mathrm{ml}$ to the $\mathrm{HC}$ epithelial cells $\left(p<0.01\right.$; Fig. 4). However, $\mathrm{NH}_{3}-\mathrm{N}$ concentration as high as $200 \mu \mathrm{g} / \mathrm{ml}$ remarkably inhibited bacterial attachment to both cells $(p<0.01)$.

When 3 volatile fatty acids (VFA) were added, acetate at $70 \mathrm{~mm}$ slightly increased bacterial attachment to the LC epithelial cells, although the increase was

Table 1. Attachment of ruminal bacteria to rumen epithelial cells. ${ }^{a}$

\begin{tabular}{cccc}
\hline & & Source of epithelial cells $^{b}$ & HC \\
\cline { 2 - 4 } Bacterial fraction & LC & (Attached bacterial number/cell) & $3.6 \pm 0.71^{\mathrm{e}}$ \\
Upper & $15.6 \pm 0.64^{\mathrm{c}}$ & $5.3 \pm 0.57^{\mathrm{de}}$ & \\
Lower & $7.0 \pm 1.05^{\mathrm{d}}$ & & \\
\hline
\end{tabular}

\footnotetext{
${ }^{a}$ Means \pm standard errors within the table without common superscripts differ $(p<0.05$; SEM $=0.69)$.

${ }^{b}$ Rumen epithelial cells were obtained from the steer fed low-concentrate (LC) or high-concentrate (HC) diets.
} 


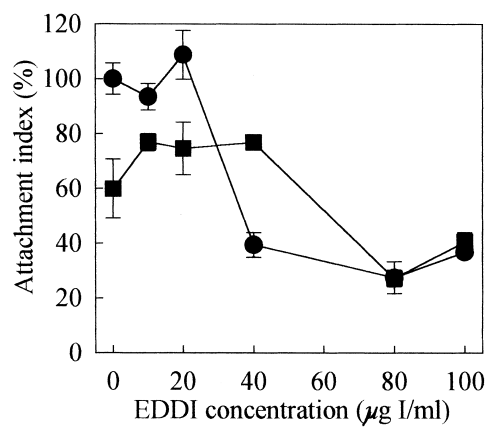

Fig. 3. Effect of EDDI on attachment of ruminal bacteria (the $U$ fraction) to rumen epithelial cells.

Results are presented as means and standard errors (bars) of three separate experiments, with the bacterial number on LC epithelial cells with no addition of EDDI as 100. Rumen epithelial cells were from steers fed: $\bullet$, LC diet; $\boldsymbol{\square}, \mathrm{HC}$ diet.

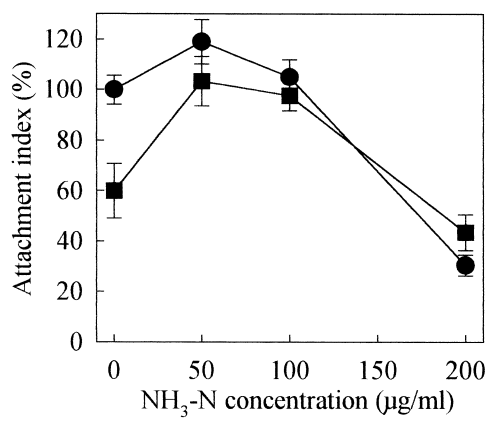

Fig. 4. Effect of ammonia on attachment of ruminal bacteria (the $U$ fraction) to rumen epithelial cells.

Results are presented as means and standard errors (bars) of three separate experiments, with the bacterial number on LC epithelial cells with no ammonia addition as 100. Rumen epithelial cells were from: $\bullet$ LC diet; $\mathbf{\square}, \mathrm{HC}$ diet.

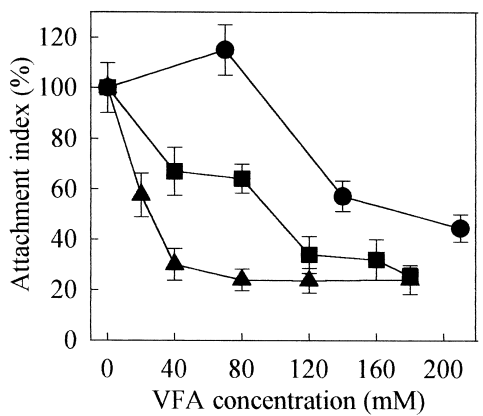

Fig. 5. Effect of VFA on attachment of ruminal bacteria to rumen epithelial cells.

The $U$ fractional bacteria and LC epithelial cells were used. Results are presented as means and standard errors of attachment indexes in three separate experiments $(n=9)$, with the bacterial number with no VFA addition as 100 . The VFAs were: $\bullet$, acetate; $\mathbf{\square}$, propionate; $\boldsymbol{\Lambda}$, butyrate.

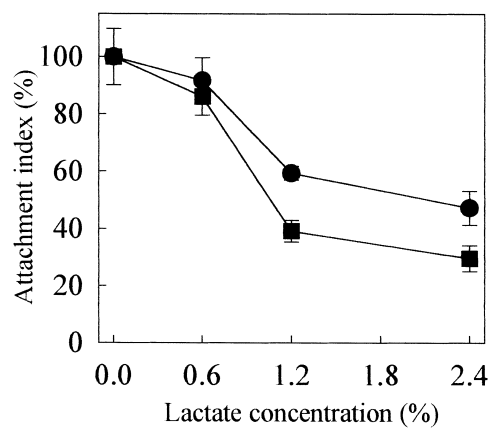

Fig. 6. Effect of L- and D-lactic acids on attachment of ruminal bacteria to rumen epithelial cells.

The $U$ fractional bacteria and LC epithelial cells were used. Results are presented as means and standard errors of attachment indexes in three separate experiments, with the bacterial number with no lactate addition as 100 . The lactic acids were: $\bullet$, L-lactic acid; $\mathbf{\square}$, D-lactic acid.

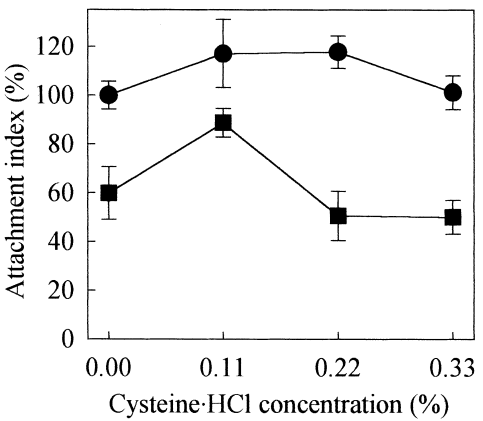

Fig. 7. Effect of reducing agent $(\mathrm{L}$-cysteine $\cdot \mathrm{HCl})$ on attachment of ruminal bacteria (the $U$ fraction) to rumen epithelial cells.

Results are presented as means and standard errors (bars) of attachment indexes in three separate experiments $(n=9)$, with the bacterial number on the LC epithelial cells with no cysteine $\cdot \mathrm{HCl}$ addition as 100. Rumen epithelial cells were from steers fed: $\bullet$, LC diet; $\mathbf{\square}, \mathrm{HC}$ diet.

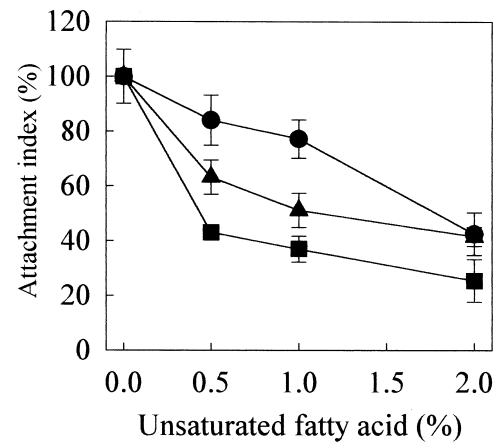

Fig. 8. Effect of unsaturated fatty acids on attachment of ruminal bacteria to rumen epithelial cells.

The $U$ fractional bacteria and LC epithelial cells were used. Results are presented as means and standard errors (bars) of attachment indexes in three separate experiments $(n=9)$, with the bacterial number with no addition of unsaturated fatty acids as 100 . The unsaturated fatty acids were: $\boldsymbol{\bullet}$, oleic acid; $\boldsymbol{\Lambda}$, linoleic acid; $\mathbf{\square}$, arachidonic acid. 
not significant $(p>0.05)$. Attachment was reduced when the acetate concentration exceeded $70 \mathrm{~mm}$. Propionate and butyrate at any concentration inhibited bacterial attachment to the epithelial cells (Fig. 5).

Lactate always showed a negative effect on bacterial attachment to the rumen epithelium, no matter what isomers were used (Fig. 6). When lactate concentration exceeded $0.6 \%$, attachment indexes became dramatically low, especially with the addition of D-lactate.

$\mathrm{L}$-Cysteine $\cdot \mathrm{HCl}$ as a reducing agent added at $0.11 \%$ showed a positive effect on bacterial attachment to the $\mathrm{HC}$ epithelial cells $(p<0.05)$; a similar but non-significant $(p>0.10)$ effect was noted with the LC cells as compared to the untreated control (Fig. 7).

Of all of the unsaturated fatty acids examined, arachidonic acid was found to be the greatest inhibitor for bacterial attachment to the rumen epithelium, followed by linoleic acid and oleic acid (Fig. 8).

\section{Discussion}

Bacterial attachment and subsequent colonization to the gastrointestines of animals are believed to be the key initial steps by which most bacterial populations establish within the gut (Freter, 1992). The attachment by normal (Conway and Adams, 1989; Greene and Klaenhammer, 1994; Toba et al., 1995) or pathogenic bacteria (Corthesy-Theulaz et al., 1996; Kobayashi et al., 1993; Lindquist et al., 1987) was extensively investigated using in vitro assays. The in vitro assay for bacterial attachment to rumen epithelial cells, however, is less reported. To examine the influence of diet-related factors on bacterial attachment to rumen epithelia, in this study, we used an in vitro model system that consisted of mixed ruminal bacteria and ruminal epithelial cells. In vitro incubation conditions of $39^{\circ} \mathrm{C}$ for $30 \mathrm{~min}$, were found to be optimal for studies of bacterial attachment to rumen epithelial cells.

Previous studies have shown that a large population of ruminal bacteria attach to rumen epithelia (Bauchop et al., 1975; McCowan et al., 1978, 1980; Rieu et al., 1990; Wallace et al., 1979) and the attachment is probably mediated by certain carbohydrates or glycocalyx complexes that surround the bacteria (Cheng and Costerton, 1980; Latham et al., 1978; McCowan et al., 1980; Owens and Goetsch, 1988; Wallace et al., 1979). Our recent study (Meng and Preston, 1997) showed that certain lectin components, proteins or glycoproteins were present on ruminal bacteria, and the lectin activity varied among bacterial fractions collected by centrifugation. From this study, when LC epithelial cells were used, a higher attaching activity was detected for the $U$ fractional bacteria than for the $\mathrm{L}$ fractional bacteria. This result indicated that the bacteria that are associated with attachment to rumen epithelia may be mostly present in the upper layer rather than the lower layer of the fraction. The bacterial attaching activity obtained from the current study followed a similar pattern of lectin activity of the ruminal bacteria (Meng and Preston, 1997), suggesting that lectins may mediate bacterial attachment to the ruminal epithelium. The higher attaching activity of the $U$ fractional bacteria than that of the $L$ fractional bacteria did not occur with $\mathrm{HC}$ epithelial cells (Table 1). This observation was an indication that the bacteria from the steer fed a roughage diet have an attaching preference to the rumen epithelial cells from steers fed a low-concentrate diet relative to the epithelial cells from animals fed a high-concentrate diet.

Some dietary components and rumen fermentation products affected bacterial attachment to the rumen epithelium. Bacterial attachment to the $\mathrm{HC}$ epithelial cells (Fig. 3 ) increased with the addition of EDDI from 10 through $40 \mu \mathrm{g} \mathrm{l} / \mathrm{ml}$. The exact reason for this increase is unclear. In vivo, EDDI inhibits proliferation of some pathogenic bacteria like Fusobacterium necrophorum and Bacteroides melaninogenicus (Siddique et al., 1992), which may be unfavorable to the attachment of other ruminal bacteria to the epithelia. In this in vitro study, because the majority of the bacteria were washed off the epithelia prior to the experiment, other mechanisms may be involved in the attachment with EDDI addition. Ammonia- $N$ at 50 through $100 \mu \mathrm{g} / \mathrm{ml}$ increased bacterial attachment to the $\mathrm{HC}$ and to some extent the LC ruminal epithelial cells $(p<0.01)$ as compared to the control (Fig. 4). This result may be due to basicity of ammonia that can neutralize or alleviate acidity on the surface of ruminal epithelial cells resulting from fermentation of the $\mathrm{HC}$ diet in the rumen. A proper $\mathrm{pH}$ (not tested) would seem to be essential for bacterial attachment to the ruminal epithelium. Some studies showed evidence for $\mathrm{pH}$-dependent attachment of Helicobacter pylori to polarized human intestinal cell monolayers (CorthesyTheulaz et al., 1996) and of Lactobacilli to the human colon cell line (Greene and Klaenhammer, 1994). Lactate and VFA were generally found to inhibit bacterial attachment to the rumen epithelium. Because of the variance in inhibitory attachment activity occurring between the three VFAs (Fig. 5) and the two lactate isomers (Fig. 6), it seems that not only the acidity but also other mechanisms may be responsible for the inhibition of attachment. Since the rate of VFA absorption through the rumen epithelium (Danielli et al., 1945 ) is in line with their relative effect on attachment, this may be the mechanism regulating epithelial response. The inclusion of L-cysteine $\cdot \mathrm{HCl}$ as a reducing agent at $0.11 \%$ resulted in an increase in bacterial at- 
tachment to the $\mathrm{HC}$ epithelial cells $(p<0.01)$, but no significant increase $(p>0.10)$ was found for attachment to the LC epithelial cells (Fig. 7). This result indicates that, when cattle are fed a high-concentrate diet, maintenance of a low oxidation-reduction potential may facilitate bacterial attachment to rumen epithelia. Three unsaturated fatty acids also inhibited bacterial attachment to the rumen epithelium (Fig. 8). Although biohydrogenation of unsaturated fatty acids by bacteria occurring in the rumen is well known, the process is less complete when a high-concentrate diet is fed as compared to a low-concentrate diet (Latham et al., 1972). Therefore, when ruminants are fed high-concentrate diets, bacterial attachment inhibition by unsaturated fatty acids hydrolyzed from dietary fats in the rumen may be important.

Bacterial attachment to ruminal epithelia is an important feature in ruminant animals and may play a special role in promoting certain ruminal bacterial ecosystems. Although attached bacterial floras have been shown to exist independent of rumen fluid and feed particle-adhered bacteria (Wallace et al., 1979), from our study, approximately 30 to $50 \%$ (calculated from the number of attached bacteria divided by the total added bacteria) of the $U$ fractional bacteria had the ability to attach to the LC rumen epithelial cells, which suggests that a relatively large portion of bacteria in the rumen liquid phase can attach to the rumen epithelium. Thus, we would speculate that the proportion of bacteria present in the liquid phase of rumen that becomes attached is likely to be the result of specific selection by integration between rumen epithelial receptors and bacterial surface lectins. Thus, any changes in rumen epithelial receptors or in bacterial lectins caused directly or indirectly by diets, fermentation metabolites or other factors would result in alterations in the rumen bacterial ecosystem.

This article has been approved for publication by the Dean of the Agric. Sci. and Natl. Res. as publ. No. T-5-356. Funds for this study were provided by the Thornton Endowment, Texas Tech Univ., Lubbock, TX, U.S.A.

\section{References}

Bauchop, T., Clark, R. T. J., and Newhook, J. C. (1975) Scanning electron microscope study of bacteria associated with the rumen epithelium of sheep. Appl. Microbiol., 30, 668-675.

Cheng, K. J. and Costerton, J. W. (1980) Adherent rumen bacteria: Their role in the digestion of plant material, urea and epithelial cells. In Digestion Physiology and Metabolism in Ruminants, ed. by Ruckebusch, Y. and Thivend, P., AVI Publishing Co., Westport, CT, pp. 227-250.

Cheng, K. J. and Wallace, R. J. (1979) The mechanism of passage of endogenous urea through the rumen wall and the role of ureolytic epithelial bacteria in the urea flux. Br. J. Nutr., 42, 553-557.

Coleman, G. S. (1987) Rumen entodiniomorphid protozoa. In In
Vitro Methods for Parasite Cultivation, ed. by Taylor, A. E. R. and Baker, J. R., Academic Press, New York, pp. 29-51.

Conway, P. L. and Adams, R. F. (1989) Role of erythrosine in the inhibition of adhesion of Lactobacillus fermentum strain 737 to mouse tissue. J. Gen. Microbiol., 135, 1167-1173.

Corthesy-Theulaz, I., Porta, N., Pringault, E., Racine, L., Bogdanova, A., Kraehenbuhl, J. P., Blum, A. L., and Michetti, P. (1996) Adhesion of Helicobacter pylori to polarized $T_{84}$ human intestinal cell monolayers is $\mathrm{pH}$ dependent. Infect. Immun., 64, 3827-3832.

Danielli, J. F., Hitchcock, M. W. S., Marshall, R. A., and Phillipson, A. T. (1945) The mechanism of absorption from the rumen as exemplified by the behavior of acetic, propionic and butyric acids. J. Exp. Biol., 22, 75-84.

Dinsdale, D., Cheng, K. J., Wallace, R. J., and Goodlad, R. A. (1980) Digestion of epithelial tissue of the rumen wall by adherent bacteria in infused and conventionally fed sheep. Appl. Environ. Microbiol., 39, 1059-1066.

Freshney, R. I. (1994) Culture of Animal Cells: A Manual of Basic Technique. Wiley-Liss, Inc., New York, pp. 71-103.

Freter, R. (1992) Factors affecting the microecology of the gut. In Probiotics: The Scientific Basis, ed. by Fuller, R., Chapman \& Hall, London, pp. 111-144.

Greene, J. D. and Klaenhammer, T. R. (1994) Factors involved in adherence of Lactobacilli to human Caco-2 cells. Appl. Environ. Microbiol., 60, 4484-4494.

Kobayashi, Y., Okazaki, K., and Murakami, K. (1993) Adhesion of Helicobacter pylori to gastric epithelial cells in primary cultures obtained from stomachs of various animals. Infect. Immun., 61, 4058-4063.

Latham, M. J., Brooker, B. E., Pettipher, G. L., and Harris, P. J. (1978) Ruminococcus flavefaciens cell coat and adhesion to cotton cellulose and to cell walls in leaves of perennial rye grass (Lolium perenne). Appl. Environ. Microbiol., 35, 156-165.

Latham, M. J., Storry, J. E., and Sharpe, M. E. (1972) Effect of lowroughage diet on the microflora and lipid metabolism in the rumen. Appl. Microbiol., 24, 871-877.

Lindquist, B. L., Lebenthal, E., Lee, P., Stinson, M. W., and Merrick, J. M. (1987) Adherence of Salmonella typhimurium to small-intestinal enterocytes of the rat. Infect. Immun., 55, 3044-3050.

McCowan, R. P., Cheng, K. J., Bailey, C. B. M., and Costerton, J. W. (1978) Adhesion of bacteria to epithelial cell surfaces within the reticulo-rumen of cattle. Appl. Environ. Microbiol., 35, 149-155.

McCowan, R. P., Cheng, K. J., and Costerton, J. W. (1980) Adherent bacterial populations on the bovine rumen wall: Distribution patterns of adherent bacteria. Appl. Environ. Microbiol., 39, 233-241.

Meng, Q. and Preston, R. L. (1994) Electron microscopy of bacteria associated with reticulo-rumen epithelium in steers fed low or high concentrate diets. Texas Tech Univ. Agric. Sci. Tech. Rep., T-5-342, 10-13.

Meng, Q. and Preston, R. L. (1997) Evidence for existence of lectins on the ruminal bacteria from steers fed roughage and high concentrate diets. J. Gen. Appl. Microbiol., 43, 81-87.

Owens, F. N. and Goetsch, A. L. (1988) Rumen fermentation. In The Ruminant Animal Digestive Physiology and Nutrition, ed. by Church, D. C., Prentice Hall, Englewood Cliffs, NJ, pp. 145-171.

Pal, R. and Ghose, A. C. (1990) Identification of plasmid-encoded mannose-resistant hemagglutinin and HEp-2 and HeLa cell adherence factors of two diarrheagenic Escherichia coli strains belonging to an enteropathogenic serogroup. Infect. Immun., 58, 1106-1113.

Rieu, F., Fonty, G., Gaillard, B., and Gouet, P. (1990) Electron microscopy study of the bacteria adherent to the rumen wall in 
young conventional lambs. Can. J. Microbiol., 36, 140-144. SAS (1989) SAS User's Guide: Statistics, SAS Inst., Inc., Cary, NC. Siddique, M. M., Bartle, S. J., and Preston, R. L. (1992) Efficiency of iodine compounds against the causative organisms of bovine footrot. Texas Tech Univ. Agric. Sci. Tech. Rep., T-5-327, $155-157$.

Toba, T., Virkola, R., Westerlund, B., Bjorkman, Y., Sillanpaa, J.,
Vartio, T., Kalkkinen, N., and Korhonen, T. K. (1995) A collagenbinding S-layer protein in Lactobacillus crispatus. Appl. Environ. Microbiol., 61, 2467-2471.

Wallace, R. J., Cheng, K. J., Dinsdale, D., and Ørskov, E. R. (1979) An independent microbial flora of the epithelium and its role in the ecomicrobiology of the rumen. Nature, 279, 424-426. 